\title{
GCU
}

Glasgow Caledonian

University

University for the Common Good

\section{Implications of parent and child injustice appraisals for child pain and functional outcomes}

McParland, Joanna L.

Published in:

PAIN

DOI:

10.1097/j.pain.0000000000001221

Publication date:

2018

Document Version

Author accepted manuscript

Link to publication in ResearchOnline

Citation for published version (Harvard):

McParland, JL 2018, 'Implications of parent and child injustice appraisals for child pain and functional outcomes', PAIN, vol. 159, no. 6, pp. 1003-1004. https://doi.org/10.1097/j.pain.0000000000001221

\section{General rights}

Copyright and moral rights for the publications made accessible in the public portal are retained by the authors and/or other copyright owners and it is a condition of accessing publications that users recognise and abide by the legal requirements associated with these rights.

Take down policy

If you believe that this document breaches copyright please view our takedown policy at https://edshare.gcu.ac.uk/id/eprint/5179 for details of how to contact us. 
A consistent body of research suggests that perceiving severe and irreparable loss alongside a high level of blame and unfairness in relation to pain has negative implications for physical and mental health outcomes among adults with a long-term pain condition [9]. Together, these core ingredients of pain-related injustice appraisals may be detrimental because, in their intuitive aversion to injustice, the thoughts, feelings and behaviour of those experiencing pain may be disrupted by it. The conception of an injustice is first and foremost subjective in nature. The point at which pain might be interpreted in this way will be influenced by various factors that may occur singly or in combination, such as whether an external agent is considered responsible for the onset of pain, how effectively pain is managed medically and whether adequate support is received from relevant others [5].

Since its inception 10 years ago, research examining the role of justice-related cognitions in the context of pain has proceeded in different directions. In this issue of PAIN, Miller et al. report a novel study exploring the effects of third party, proximal other appraisals of injustice in relation to pain. Their key focus of investigation is the effect of concordant and discordant perceptions of injustice for child pain among treatment-seeking parent-child dyads, on child pain and functional outcomes. The authors highlight the relevance of this research by drawing on an associated literature that has shown discordant parent-child catastrophizing appraisals have important repercussions for child pain $[2,6]$.

Within the Miller et al. study [4] injustice appraisals were examined using modified versions of the Injustice Experience Questionnaire (IEQ) [7] to reflect the perspective of the parent and child, for example "I should not have to live this way" or "My child should not have to live this way". Child-parent dyads were categorized into one of four categories of concordance or discordance (high or low) based on their scores on the IEQ. Measured outcomes included pain intensity, stress, functional disability and quality of life. 
There are several new and thought-provoking findings. Parents reported a significantly higher level of perceived injustice than their child, although most of the dyads were concordant in their views. In other words, most parents and their child held a similar perspective of loss, blame and unfairness in relation to the child's pain. Parental ratings of injustice were correlated with poor child outcomes, but these effects were strongest among children with higher injustice ratings and, also in dyads containing children with high perceptions of injustice, specifically those in the 'concordant high' and 'discordant high child - low parent' groups. As the authors rightly suggest, these findings indicate that, consistent with the pattern of findings in the only other paediatric study [3] and within the adult literature in general, child appraisals of their own injustice are the primary drivers of pain and functional outcomes. Nevertheless, perhaps the most interesting finding is that among all concordant and discordant groups, the worst outcomes were observed in the discordant group where the child had a higher level of perceived injustice than their parent. The authors propose the adverse effects of this discrepancy may be due to the child's heightened display of pain behaviour that is used to communicate the severity of their suffering to their parent, whom they perceive as not taking their pain seriously. This is a plausible interpretation that, as noted, is consistent with the association between perceived injustice, heightened pain behaviour and adverse outcomes observed in adult samples [8]. Going forward, there are many exciting opportunities to explore, including the nature and impact of the child's emotional and other reactions to their injustice appraisals, in addition to the parental response to the child's protestations of injustice. It is intriguing that, within these discordant dyads, the parental injustice ratings were clinically significant. As indicated in the discussion, it will be useful in future to investigate whether these findings will be replicated with parents who do not have such significant ratings. 
Although the authors explain their findings well in relation to relevant literature, interpretation is still somewhat precluded by the lack of key information on the characteristics of the participants. This includes facts about the gender of the parent, duration of diagnosis and number of clinic appointments attended, all of which could be hypothesised to influence pain-related injustice appraisals and associated child outcomes. This is an important study limitation that is acknowledged. What is known is that the composition of the parent-child dyads is not influenced by the age of the child. A second recorded qualification is that the generalizability of the findings is potentially limited by the fact that the children were predominantly white and female, from one clinic. They were also mostly adolescents. This is a relevant consideration because adolescents can differ from children in how they evaluate and form justice judgements. As recognised by the authors, parents often influence the development of their child's justice beliefs [1]. This is more likely to be true of younger children whose lives are shaped by the family context than older children who may be most influenced by other areas of life involving, for example, peers and school. Therefore, it may be worthwhile for future research to investigate injustice appraisals in separate child and adolescent contexts.

Several important directions for future research are provided. One key recommendation is to explore the potential independent effects of the blame/unfairness and severity/irreparability of loss subscales of the IEQ to determine the level of concordance and discordance in each subscale within parent-child dyads and the implications of each for child outcomes. Making this distinction would also identify whether either subscale is most meaningful to the painrelated justice reasoning of the parent and the child.

Miller et al. have shown that the parent has an important role to play in pain-related injustice appraisals in the context of pediatric pain. They provide much opportunity for 
testable hypotheses to be generated. Future research should proceed in a systematic way to maximise learning and guide clinical interventions in this emerging field of inquiry.

\section{Conflict of interest statement}

The author has no conflict of interest to declare. 


\section{References}

[1] Dalbert C, Radant M. Parenting and young adolescents' belief in a just world. In: Dalbert C, Sallay H, editors. The justice motive in adolescence and young adulthood: Origins and consequences. London: Routledge, 2004, pp.11-25.

[2] Lynch-Jordan AM, Kashikar-Zuck S, Szabova A, Goldschneider KR. The interplay of parent and adolescent catastrophizing and its impact on adolescents' pain, functioning and pain behavior. Clin J Pain 2013;29:681-688.

[3] Miller MM, Scott EL, Trost Z, Hirsh AT. Perceived injustice is associated with pain and functional outcomes in children and adolescents with chronic pain: A preliminary examination. J Pain 2016;17:1217-1226.

[4] Miller MM, Wuest D, Williams AE, Scott EL, Trost Z, Hirsh AT. Injustice perceptions about pain: Parent-child discordance is associated with worse functional outcomes. PAIN 2018.

[5] Scott W, McEvoy A, Garland R, Bernier E, Milioto M, Trost Z, Sullivan M. Sources of injustice among individuals with persistent pain following musculoskeletal injury. Psychol Inj Law 2016;9:6-15.

[6] Sil S, Dampier C, Cohen LL. Pediatric Sickle Cell Disease and Parent and Child Catastrophizing. J Pain 2016;17:963-971.

[7] Sullivan MJ, Adams H, Horan S, Maher D, Boland D, Gross R. The role of perceived injustice in the experience of chronic pain and disability: scale development and validation. J Occup Rehabil 2008;18:249-261.

[8] Sullivan MJ, Davidson N, Garfinkel B, Siriapaipant N, Scott W. Perceived injustice is associated with heightened pain behavior and disability in individuals with whiplash injuries. Psychol Inj Law 2009;2:238-247. 
[9] Sullivan MJ, Yakobov E, Scott W, Tait R. Perceived injustice and adverse recovery outcomes. Psychol Inj Law 2014;7(4):325-334. 